\title{
Kepatuhan Penggunaan Obat pada Komunitas Pasien Lanjut Usia dengan Penyakit Kronis di Kecamatan Muntilan Jawa Tengah
}

\author{
Medication Adherence in Elderly Patients with Chronic Disease Based on \\ Community in Muntilan District Central Java
}

\author{
Emerentiana Wikan', Fita Rahmawati2 ${ }^{*}$, Izyan Abdul Wahab ${ }^{1}$ \\ ${ }^{1}$ Magister Farmasi Klinik, Fakultas Farmasi Universitas Gadjah Mada \\ ${ }^{2}$ Fakultas Farmasi Universitas Cyberjaya, Malaysia \\ Corresponding author: Fita Rahmawati: Email: rahmawati_f@ugm.ac.id \\ Submitted: 28-08-2019 Revised:03-09-2019 Accepted:03-09-2019
}

\begin{abstract}
ABSTRAK
Pasien lanjut usia dengan penyakit kronis yang mendapatkan terapi jangka panjang, memiliki risiko lebih tinggi untuk tidak patuh. Kepatuhan mempunyai arti penting untuk memastikan manfaat terapeutik diterima oleh pasien. Namun, kepatuhan terhadap obat selalu menjadi masalah, terutama di kalangan orang tua. Pasien lanjut usia dengan komorbiditas multipel, memiliki risiko ketidakpatuhan yang lebih tinggi karena mereka menerima lebih dari satu macam obat. Penelitian ini bertujuan untuk mengidentifikasi tingkat kepatuhan pengobatan pada pasien lanjut usia dengan penyakit kronis. Penelitian ini menggunakan desain cross-sectional observasional yang dilakukan selama bulan April - Juni 2019. Pengumpulan data dilakukan secara purposive sampling yang melibatkan 182 pasien lanjut usia suku Jawa di Kecamatan Muntilan, Jawa Tengah. Metode pill count digunakan untuk mengukur kepatuhan pasien. Pasien dengan tingkat kepatuhan rata-rata $<80 \%$ dikategorikan sebagai tidak patuh. Hubungan antara faktor pasien lanjut usia dengan tingkat kepatuhan minum obat dianalisis menggunakan regresi sederhana. Dari hasil penelitian diperoleh tingkat kepatuhan pasien lanjut usia terhadap terapi penyakit kronis dikategorikan tidak patuh dengan rata-rata 65,53 \% \pm 26,86\%, sementara faktor demografis dan faktor klinik lainnya dari pasien lanjut usia tidak terkait. Kesimpulan dari penelitian ini adalah kepatuhan minum obat pada pasien usia lanjut suku Jawa dikategorikan tidak patuh.
\end{abstract}

Kata kunci: kepatuhan; medication adherence; pill count; Jawa; lanjut usia

\section{ABSTRACT}

Elderly patients with chronic diseases who get long-term therapy, have a higher risk for non adherence. Adherence has an important meaning to ensure therapeutic benefits was received by patients. However, adherence to medication is always be a problem, especially among the elderly. Elderly patients with multiple comorbidities have a higher risk of non-adherent because they receive more than one drug. The study aims to identify the level of adherence in elderly patients with chronic disease. Design of this study was an observational cross-sectional study conducted during April - June 2019. The data collection by purposive sampling enrolled 182 elderly Javanese patients in Muntilan District, Central Java. The pill count method was used to measure patient adherence. Patients with an average adherence level $<80 \%$ are categorized as non adherence. The relationship between factors of elderly patients with the level of adherence was analyzed using simple regression. From the results of the study obtained the level of adherence of elderly patients to chronic diseases treatment was categorized as non-adherent with an average of $65.53 \% \pm 26,86 \%$, while demographic factors and other clinical factors of elderly patients are not related. The conclusion of this study is medication adherence in elderly patients in Javanese community was categorized as not adherent. Keywords: medication adherence; pill count; Javanese; elderly

\section{PENDAHULUAN}

Populasi lanjut usia (lansia) di dunia saat ini mengalami peningkatan populasi. Di Indonesia, populasi ini mencapai lebih dari $7 \%$ pada tahun 2008, 2009 dan 2012. Di beberapa daerah, populasi ini di atas $10 \%$ dan tertinggi di Daerah Istimewa Yogyakarta $(13,04 \%)$, Jawa Timur $(10,40 \%)$ dan Jawa Tengah $(10,34 \%)$ 
(Primadi dkk., 2013). Banyak dijumpai pasien lanjut usia dengan berbagai penyakit kronis membutuhkan perawatan jangka panjang yang kompleks. Selain itu, lansia adalah konsumen terbesar obat dengan resep. Di negara maju, pasien di atas usia 60 tahun mengonsumsi sekitar 50\% dari semua obat yang diresepkan (Sabaté dan WHO, 2003).

Kepatuhan minum obat merupakan hal yang penting untuk memastikan manfaat terapeutik diterima oleh pasien. Namun, kepatuhan terhadap obat selalu menjadi masalah, terutama di kalangan orang tua. Pasien usia lanjut dengan komorbiditas multipel, memiliki risiko ketidakpatuhan yang lebih tinggi karena mereka menerima lebih dari satu obat (Yap et al., 2016). Prevalensi kognitif dan gangguan fungsional pada pasien lanjut usia meningkatkan risiko ketidakpatuhan yang buruk. Adanya komorbiditas dan rejimen medis yang kompleks semakin meningkatkan ketidakpatuhan. Perubahan farmakokinetik dan farmakodinamik akibat bertambahnya usia menyebabkan populasi ini semakin rentan terhadap masalah medis karena ketidakpatuhan pada pengobatan (Sabaté dan WHO, 2003).

Penting untuk memahami alasan ketidakpatuhan pada pengobatan untuk dapat tercapainya perubahan perilaku. Data melaporkan bahwa obat yang diresepkan pada penyakit kronis yang tidak dikonsumsi sekitar $50 \%$, dengan $20 \%$ hingga $30 \%$ dari resep bahkan tidak pernah dipenuhi. Sistematik review menyebutkan ketidakpatuhan pada pasien lanjut usia antara $40 \%$ - 75\%. Pusat Pengendalian dan Pencegahan Penyakit (Centers for Disease Control and Prevention) melaporkan kegagalan perawatan akibat ketidakpatuhan pada pengobatan antara 30\% dan $50 \%$ dan menjadi penyebab 125.000 kematian setiap tahun (Haugh, 2014). Data kunjungan ruang gawat darurat akibat masalah ketidakpatuhan penggunaan obat sebesar 70,4\% (Orwig, 2006).

Sebuah tinjauan literatur secara sistematis membandingkan berbagai pendekatan yang mengukur kepatuhan penggunaan obat pada penyakit kronis dengan polifarmasi pada pemberian oral dan subkutan. Data yang bersumber dari pencatatan di unit farmasi dan catatan rekam medis biasanya memberikan data yang akurat, mudah, Untuk monitoring kepatuhan penggunaan obat di rumah dapat digunakan metode penghitungan pil (pill count), sistem pemantauan elektronik (Medication Event Monitoring Systems /MEMS), kuesioner pelaporan diri dan laporan pengamatan (Forbes et al., 2018). Metode pill count dan sistem pemantauan elektronik (MEMS) merupakan metode yang secara objektif digunakan untuk mengevaluasi kepatuhan pengobatan (Haugh, 2014).

\section{METODE}

\section{Rancangan Penelitian}

Penelitian ini bersifat observasional dengan rancangan cross sectional yang dilakukan terhadap komunitas pasien lanjut usia di Kecamatan Muntilan Jawa Tengah pada bulan April - Juni 2019.

\section{Subyek Penelitian}

Subyek penelitian merupakan pasien lanjut usia yang mendapatkan terapi penyakit kronis. Kriteria inklusi pasien yaitu pasien lanjut usia $\geq 60$ tahun, menerima terapi obat untuk penyakit kronis, suku Jawa. Sedangkan kriteria ekslusinya adalah pasien yang menolak diikutsertakan dalam penelitian ini. Penelitian ini sudah mendapatkan ethical approval dari Fakultas Kedokteran Universitas Gadjah Mada

\section{Pengumpulan data}

Pengambilan sampel dilakukan dengan teknik purposive sampling. Metode perhitungan jumlah obat menggunakan metode pill count. Wawancara dan perhitungan jumlah obat membutuhkan waktu 15-30 menit per pasien.

\section{Pengukuran}

Metode pill count digunakan untuk mengukur kepatuhan penggunaan obat pada pasien lanjut usia dengan melakukan penghitungan sisa obat yang digunakan pasien pada terapi penyakit kronis untuk mendapatkan persen kepatuhan dengan menggunakan rumus Grymonpre (Grymonpre, 1998). Pasien disebut patuh jika diperoleh persen kepatuhan $\geq 80 \%$

\section{Analisis statistik}

Uji statistik penelitian ini menggunakan Statistical Package for the Social Science (SPSS) 23.0. Data sosiodemografi digambarkan secara deskriptif. Data karakteristik dibagi menjadi beberapa kategori. Tes Mann-Whitney dan Kruskal-Wallis digunakan untuk mengeksplorasi perbedaan antara kepatuhan pasien lanjut usia dalam karakteristik pasien. Uji 
Tabel I. Karakteristik Pasien Lanjut Usia

\begin{tabular}{lcccc}
\hline Karakteristik & Subyek (n=182) & Persentase & Mean \pm SD & p value \\
\hline Jenis kelamin & & & & \\
$\quad$ Wanita & 102 & $56 \%$ & $65.46 \pm 27.54$ & $0.907^{\mathrm{b}}$ \\
$\quad$ Pria & 80 & $44 \%$ & $65.63 \pm 26.13$ & \\
Usia (tahun) & & & & \\
$\quad 00-69$ & 119 & $65.4 \%$ & $69.02 \pm 25.61$ & $0.296^{\mathrm{a}}$ \\
$70-79$ & 45 & $24.7 \%$ & $63.53 \pm 28.50$ & \\
$\geq 80$ & 18 & $9.9 \%$ & $56.16 \pm 29.82$ & \\
$\quad$ Status & & & & \\
Pernikahan & 174 & $95.6 \%$ & $65.64 \pm 27.11$ & $0.628^{\mathrm{b}}$ \\
$\quad$ Menikah & 8 & $4.4 \%$ & $63.25 \pm 21.76$ & \\
$\quad$ Tidak menikah & & & & \\
Pekerjaan & 158 & $86.8 \%$ & $65.65 \pm 27.65$ & $0.574^{\mathrm{b}}$ \\
$\quad$ Tidak bekerja & 24 & $13.2 \%$ & $64.79 \pm 21.36$ & \\
$\quad$ Bekerja & &
\end{tabular}

*statistik significant $(\mathrm{p}<0,05)$, one tailed; a. Kruskal Wallis test; b. Mann-Whitney test

regresi sederhana digunakan untuk mengetahui pengaruh faktor pasien lansia dengan tingkat kepatuhan penggunaan obat.

\section{HASIL DAN PEMBAHASAN}

Karakteristik Sosiodemografi Pasien Lanjut Usia

Dari penelitian diperoleh data sebanyak 182 pasien lanjut usia suku Jawa yang sedang menjalani terapi pada penyakit kronis. Berdasarkan karakteristik sosiodemografi pasien lanjut usia pada Tabel I, sebagian besar pasien berusia $60-69$ tahun $(65,4 \%)$ dengan usia rata-rata $68,92 \pm 6,71$ dengan rentang usia berkisar antara 60 - 92 tahun. Sebagian besar pasien adalah perempuan (56\%), telah menikah $(95,6 \%)$ dan tidak bekerja $(86,8 \%)$. Tidak ada perbedaan yang signifikan secara statistik antara karakteristik sosiodemografi pasien lanjut usia dalam hal kepatuhan pengobatan pada penyakit kronis.

Mayoritas pasien wanita merupakan subyek dalam penelitian ini. Sesuai dengan data demografis oleh BPS, proporsi wanita lanjut usia di Indonesia lebih tinggi daripada proporsi pria lansia, harapan hidup wanita lebih tinggi daripada pria. Maka jumlah populasi wanita lanjut usia akan lebih besar daripada pria lansia (BPS, 2014). Mayoritas pasien lansia berusia 6069 tahun (65,4\%). Hasil Sensus Penduduk 2010 mencatat harapan hidup perempuan mencapai 71,74 tahun, lebih tinggi dari laki-laki yang sebesar 67,51 tahun. Menurut WHO (2003) kepatuhan dipengaruhi oleh usia yang berkaitan dengan kemampuan kognitif, namun dari hasil penelitian ini pengaruh tingkat usia terhadap kepatuhan penggunaan obat pasien lansia tidak menunjukkan perbedaan yang signifikan. Sebagian besar pasien tidak bekerja $(86,8 \%)$ saat dalam perawatan penyakit kronis dan secara statistik, tidak ada perbedaan yang signifikan antara pekerjaan sebagai karakteristik demografi pasien lanjut usia dengan tingkat kepatuhan minum obat. Kondisi ini berbeda dengan penelitian yang dilakukan Akrom dkk menyebutkan terdapat faktor yang mempengaruhi kepatuhan pasien yaitu pasien yang tidak bekerja memiliki kepatuhan 2,72 kali lebih tinggi daripada pasien yang bekerja karena terdapat waktu luang sehingga dapat mengingat jadwal minum obat dengan baik dibanding yang pasien yang bekerja (Akrom dkk, 2019).

Dari penelitian ini diperoleh data sebagian besar pasien berstatus menikah $(95,6 \%)$. Status penikahan ternyata tidak mempunyai perbedaan yang signifikan dengan kepatuhan minum obat meskipun studi lain menyatakan bahwa penyakit dan pengobatan dapat menyebabkan perubahan dalam peran pasangan, yang dapat membebani dinamika hubungan perkawinan (Wolff dan Kasper, 2006).

Terdapat beberapa faktor ketidakpatuhan terhadap pengobatan termasuk faktor motivasi, tingkat pengetahuan terhadap penyakit dan tujuan terapi itu sendiri (Sabaté and WHO, 2003). 
Tabel II. Karakteristik Klinik Pasien Lanjut Usia

\begin{tabular}{lcccc}
\hline Karakteristik klinik & Subyek (n=182) & Persentase & Mean SD & p value \\
\hline Jumlah pil per hari & 69 & $37.9 \%$ & $68.26 \pm 23.56$ & $0.032^{\mathrm{b}}$ \\
$1-2$ & 58 & $31.9 \%$ & $67.68 \pm 26.67$ & \\
$3-4.5$ & 50 & $27.5 \%$ & $56.82 \pm 30.15$ & \\
$5-6$ & 5 & $2.7 \%$ & $90.20 \pm 4.08$ & \\
$7-8$ & & & & \\
Jenis penyakit & 119 & $65.4 \%$ & $65.66 \pm 26.54$ & $0.380^{\mathrm{b}}$ \\
$\quad$ Hipertensi dan penyakit & & & & \\
kasdiovaskular & 42 & $23.1 \%$ & $62.73 \pm 28.57$ & \\
Diabetes mellitus & 3 & $1.6 \%$ & $67.00 \pm 19.67$ & \\
TBC and asma & 1 & $0.5 \%$ & 8.00 & \\
Kanker & 2 & $1.1 \%$ & $87.50 \pm 17.67$ & \\
Hiperthyroid & 3 & $1.6 \%$ & $85.33 \pm 14.04$ & \\
Prostat & 5 & $2.7 \%$ & $82.00 \pm 21.08$ & \\
Stroke & 2 & $1.1 \%$ & $47.50 \pm 26.16$ & \\
Osteoporosis & 2 & $1.1 \%$ & $76.50 \pm 9.19$ & \\
Demensia & 3 & $1.6 \%$ & $60.33 \pm 30.17$ & \\
Depresi & & & & \\
\hline
\end{tabular}

*statistik significant $(\mathrm{p}<0,05)$, one tailed; a. Kruskal Wallis test; b. Mann-Whitney test

\section{Karakteristik Klinik Pasien Lanjut Usia}

Karakteristik klinik pasien lanjut usia pada penelitian ini meliputi jumlah obat dan jenis penyakit dapat dilihat pada Tabel II. Pasien lanjut usia paling banyak mengonsumsi lebih dari 2 pil per hari $(62,1 \%)$. Jumlah pil yang diminum tidak menunjukkan perbedaan yang signifikan secara statistik terhadap kepatuhan pengobatan (p-value 0,032 ). Jenis penyakit yang diderita pasien lanjut usia tidak menunjukkan perbedaan yang signifikan secara statistik terhadap kepatuhan pengobatan (p-value 0,380), meskipun menurut WHO (2003) kepatuhan pengobatan dipengaruhi oleh jenis penyakit.

\section{Tingkat Kepatuhan Minum Obat}

Pengobatan kronis pada pasien lanjut usia dalam penelitian ini mirip dengan laporan WHO (2003) dengan rata-rata terjadi ketidakpatuhan obat di negara berkembang sebesar 50\%. Persentase kepatuhan pengobatan menurut penyakit pada penelitian ini (tabel II) adalah hipertensi dan penyakit kardiovaskular 65,44\%, diabetes mellitus $62,73 \%$, TBC dan asma $67 \%$, kanker payudara $8 \%$, hipertiroid $87,5 \%$, prostat $85,33 \%$, stroke $82 \%$, demensia $76,50 \%$, depresi $60,33 \%$.

Hasil pengukuran kepatuhan penggunaan obat dengan metode pill count pada pasien lanjut usia suku Jawa dalam penelitian ini diperoleh persentase kepatuhan sebesar 40,7\% dan ketidakpatuhan 59,3\%. Pasien disebut patuh jika diperoleh persen kepatuhan $\geq 80 \%$ (Grymonpre, 1998). Rata-rata ketidakpatuhan pada pasien lanjut usia pada penelitian ini sebesar $65,53 \% \pm 26,86 \%$ yang berarti masuk dalam kategori tidak patuh. Hasil penelitian tentang tingkat kepatuhan terhadap pengobatan penyakit kronis pasien usia lanjut suku Jawa dapat dilihat pada tabel III.

Beberapa faktor yang terkait dengan ketidakpatuhan penggunaan obat adalah lupa, stres psikososial, kecemasan tentang kemungkinan efek samping, motivasi rendah, pengetahuan dan keterampilan yang tidak memadai dalam mengelola gejala dan pengobatan penyakit, keyakinan negatif tentang kemanjuran pengobatan, kesalahpahaman dan tidak menerima kondisi penyakitnya, tidak percaya pada diagnosis dan kesalahpahaman tentang instruksi perawatan (Sabaté dan WHO, 2003). Beberapa alasan terungkap berdasarkan wawancara saat melakukan identifikasi kepatuhan pengobatan. Alasan tersebut antara lain pasien lupa, obat yang diminum terlalu banyak, fakor biaya, pasien merasa bosan, pasien merasa lebih baik ketika menghentikan terapi, merasa tidak ada peningkatan dari penyakit dan beberapa dari mereka menghentikan terapi dan berganti ke obatobatan herbal. 
Tabel III. Tingkat Kepatuhan Penggunaan Obat pada Pasien Lanjut Usia

\begin{tabular}{lcc}
\hline Pengukuran & Jumlah Persentase (\%) & Mean \pm SD \\
\hline Compliance $(\geq 80 \%)$ & $74(40.7)$ & \\
Incompliance $(<80 \%)$ & $108(59.3)$ & \\
Total & $182(100)$ & \pm 26.86 \\
Mean & 65.53 & \pm 2.06 \\
\hline
\end{tabular}

Penggunaan herbal adalah hal yang umum dijumpai pada masyarakat Jawa sebagai warisan sejak zaman kuno hingga generasi berikutnya. Tenaga kesehatan perlu bertanya dan menggali lebih dalam tentang penggunaan obat komplementer pada pasien penyakit kronis, pasien yang kambuh atau pasien dengan kepatuhan rendah terhadap terapi yang ditentukan. Pasien yang menggunakan obat komplementer dimungkinkan untuk menghentikan atau bahkan menolak obat konvensional (Akrom dkk., 2019). Sebuah studi tinjauan sistematis memberikan hasil prevalensi penggunaan obat komplementer/alternatif berkisar antara 9\% hingga 65\% (Ernst, 2000).

Ketidakpahaman pasien akibat kurangnya pengetahuan akan meningkatkan ketidakpatuhan pasien dalam minum obat. Faktor-faktor ini berasal dari kurangnya informasi dan komunikasi antara petugas kesehatan dengan pasien. Akibat kurangnya informasi terkait proses pengobatan menyebabkan pasien mengatur sendiri terapi obat yang diterima (Ramadona, 2011). Penelitian yang dilakukan Dhewi dkk di Kabupaten Pati Jawa Tengah, menunjukkan ada hubungan yang signifikan antara pengetahuan dan kepatuhan untuk minum obat TB paru dengan nilai p 0,000 (Dhewi dkk., 2012). Penelitian lebih lanjut diperlukan untuk mengungkap fenomena ini terkait faktor pengaruh ketidakpatuhan pasien lanjut.

Intervensi untuk meningkatkan kepatuhan pengobatan pada pasien lanjut usia sangat kompleks dan disesuaikan dengan faktor penyebab ketidakpatuhan. Strategi untuk meningkatkan kepatuhan pengobatan pada pasien lanjut usia termasuk pendekatan edukatif dan perilaku. Intervensi yang tepat dapat mempengaruhi kepatuhan pengobatan pada orang tua, bekerjasama dengan generasi saat ini untuk mengembangkan rencana yang memenuhi kebutuhan mereka dan menggunakan intervensi yang dapat diterima sesuai dengan kondisi dan usia pasien lanjut usia (Oliviera, et al., 2017).

\section{KESIMPULAN}

Pada penelitian ini tidak terdapat hubungan signifikan secara statistik antara ketidakpatuhan penggunaan obat dengan faktor sosiodemografi dan karakteristik klinik pasien lanjut usia. Tingkat kepatuhan pasien lanjut usia yang menjalani pengobatan penyakit kronis sebesar $65,53 \% \pm 26,86 \%$ dan termasuk dalam kategori tidak patuh.

\section{DAFTAR PUSTAKA}

Akrom., Sari, O.M., Urbayatun, S., Saputri, Z., 2019. Analisis Determinan Faktor-Faktor yang Berhubungan dengan Kepatuhan Minum Obat Pasien Diabetes Tipe 2 Di Pelayanan Kesehatan Primer. Jurnal Sains Farmasi \& KlinisVol. 6 No. 1 (April 2019) | pp. $54-62$

Dhewi I.G., Armiyatie. Y., Supriyono. M., 2012. Hubungan Antara Pengetahuan, Sikap Pasien dan Dukungan Keluarga dengan Kepatuhan Minum Obat Pada Pasien TB Paru di BPKM Pati. http://ejournal.stikestelogorejo.ac.id/in dex.php/ilmukeperawatan/article/ view/89 akses in 3 June 2018 11:21 AM

Ernst, E., 2000. Prevalence of use of complementary/alternative medicine: A systematic review. Bull. World Health Organ. 78, 258-266.

Forbes, C.A., F., Deshpande. S., Sorio-Vilela, F., Kutikova, L., Duffy, S., Gouni-Berthold, J.,Hagström, E., 2018. A systematic literature review comparing methods for the measurement of patient persistence and adherence, Current Medical Research and Opinion.

Grymonpre, R.E., Didur, C.D., Montgomery, P.R., Sitar, D.S., 1998. Pill Count, Self-Report, and Pharmacy Claims Data to Measure Medication Adherence in the Elderly. Ann. Pharmacother. 32, 749-754. 
Haugh, K.H., 2014. Medication Adherence in Older Adults. Nurs. Clin. North Am. 49, 183-199.

Jennifer L. Wolff, Judith D. Kasper., 2006. Caregivers of Frail Elders: Updating a National Profile, The Gerontologist, Volume 46, Issue 3, June 2006, Pages 344-356.

Jorge de Sousa Oliveira, C., José, H., Castro Caldas, A., 2017. Interventions to Improve Medication Adherence in Aged People with Chronic Disease - Systematic Review. Univers. J. Public Health 5, 25-31.

Orwig, D., 2006 Medication Management Assessment for Older. The Gerontologist Vol. 46, No. 5, p. 661-668.
Primadi O., 2013, Data dan Informasi Kesehatan Semester 1 2013, Buletin Jendela Lansia. Kemenkes RI, Jakarta.

Ramadona, A., 2011. Pengaruh Konseling Obat Terhadap Kepatuhan Pasien Diabetes Mellitus Tipe 2 Di Poliklinik Khusus Rumah Sakit Umum Pusat dr. M. Djamil Padang. Tesis. Padang: Universitas Andalas.

Sabaté, E., World Health Organization (Eds.)., 2003. Adherence to long-term therapies: evidence for action. World Health Organization, Geneva.

Yap, A.F., Thirumoorthy, T., and Kwan, Y.H., 2016. Medication adherence in the elderly. J. Clin. Gerontol. Geriatr. 7, 64-67. 